\title{
Complete internal audit of a mammography service in a reference institution for breast imaging*
}

\author{
Auditoria interna completa do serviço de mamografia em uma instituição de referência \\ em imaginologia mamária
}

\author{
Gustavo Machado Badan ${ }^{1}$, Décio Roveda Júnior ${ }^{2}$, Carlos Alberto Pecci Ferreira ${ }^{3}$, Ozeas Alves de Noronha \\ Junior 4
}

Badan GM, Roveda Júnior D, Ferreira CAP, Noronha Junior OA. Complete internal audit of a mammography service in a reference institution for breast imaging. Radiol Bras. 2014 Mar/Abr;47(2):74-78.

Abstract Objective: Undertaking of a complete audit of the service of mammography, as recommended by BI-RADS ${ }^{\circledR}$, in a private reference institution for breast cancer diagnosis in the city of São Paulo, SP, Brazil, and comparison of results with those recommended by the literature.

Materials and Methods: Retrospective, analytical and cross-sectional study including 8,000 patients submitted to mammography in the period between April 2010 and March 2011, whose results were subjected to an internal audit. The patients were followed-up until December 2012.

Results: The radiological classification of 7,249 screening mammograms, according to BI-RADS, was the following: category 0 (1.43\%), 1 (7.82\%), 2 (80.76\%), 3 (8.35\%), 4 (1.46\%), 5 (0.15\%) and 6 (0.03\%). The breast cancer detection ratio was 4.8 cases per 1,000 mammograms. Ductal carcinoma in situ was found in $22.8 \%$ of cases. Positive predictive values for categories 3,4 and 5 were $1.3 \%$, $41.3 \%$ and $100 \%$, respectively. In the present study, the sensitivity of the method was $97.1 \%$ and specificity, $97.4 \%$.

Conclusion: The complete internal audit of a service of mammography is essential to evaluate the quality of such service, which reflects on an early breast cancer detection and reduction of mortality rates.

Keywords: Breast cancer; Mammographic screening; BI-RADS; Audit of mammography service; Percutaneous biopsy; Positive predictive value.

Resu mo Objetivo: Realização de auditoria completa do serviço de mamografia de uma instituição privada, conforme preconizado pelo BI-RADS ${ }^{\circledR}$, e comparação dos resultados obtidos com os recomendados pela literatura em serviço de referência em diagnóstico de câncer mamário na cidade de São Paulo.

Materiais e Métodos: Estudo retrospectivo, analítico e transversal contendo casuística de 8.000 pacientes que realizaram mamografias no período de abril de 2010 a março de 2011, submetidas à auditoria, com base no resultado de sua mamografia. Houve seguimento dessas pacientes até dezembro de 2012.

Resultados: De acordo com a categorização BI-RADS, a classificação radiológica das 7.249 mamografias de rastreamento, em relação ao número de casos, foi a seguinte: categorias 0 (1,43\%), 1 (7,82\%), 2 (80,76\%), 3 (8,35\%), 4 (1,46\%), 5 (0,15\%) e 6 (0,03\%). Verificou-se taxa de detecção para câncer mamário de 4,8 casos para cada 1.000 exames realizados. 0 total de carcinoma ductal in situ foi $22,8 \%$. Foram encontrados valores preditivos positivos para as categorias 3 , 4 e 5 de 1,3\%, 41,3\% e 100\%, respectivamente. A sensibilidade do método aferida foi $97,1 \%$ e a especificidade, $97,4 \%$.

Conclusão: A auditoria interna completa do serviço de mamografia retrata a qualidade do serviço, e com isso contribui para a detecção precoce e diminuição da mortalidade relacionada ao câncer mamário.

Unitermos: Câncer de mama; Rastreamento mamográfico; BI-RADS; Auditoria em serviço de mamografia; Biópsia percutânea; Valor preditivo positivo.

* Study developed at FEMME - Laboratório da Mulher, São Paulo, SP, Brazil.

1. Specialist in Breast Imaging, MD, Second Assistant Physician, Santa Casa de São Paulo, Coordinator for the Unit of Interventional Procedures, FEMME - Laboratório da Mulher, São Paulo, SP, Brazil.

2. College Instructor, Director, Unit of Imaging Diagnosis at Santa Casa de São Paulo, Coordinator for the Unit of Radiology, FEMME - Laboratório da Mulher, São Paulo, SP, Brazil.

3. Physician Assistant, Coordinator for the Unit of Breast Imaging, Department of Medical Practice, School of Medical Sciences, Santa Casa de São Paulo, Coordinator for the Service of Mammography, FEMME - Laboratório da Mulher, São Paulo, SP, Brazil.

4. Graduate Student of Medicine at School of Medical Sciences, Santa Casa de São Paulo, São Paulo, SP, Brazil.

\section{INTRODUCTION}

Breast cancer is the most frequent type of neoplasia affecting women worldwide, both in developed and developing countries. About 226,870 new cases with 39,510 deaths were reported in the United States of America in $2012^{(1)}$. In Brazil, according to Instituto Nacional de Câncer, 52,680

Mailing Address: Dr. Gustavo Machado Badan. Rua Loureiro da Cruz, 121, ap. 121, Aclimação. São Paulo, SP, Brazil, 01529-020. E-mail: gustavobadan@hotmail.com. Received July 23, 2013. Accepted after revision October 25, 2013. 
new cases of breast cancer were estimated in 2012, corresponding to an incidence of 52 cases per 100,000 women $^{(2)}$.

According to large observational studies, the breast cancer mortality rate has decreased in $31 \%$ due principally to the contribution from annual mammographic screening programs leading to early disease detection in a considerable number of cases ${ }^{(3-5)}$.

The National Commission of Mammography of Colégio Brasileiro de Radiologia e Diagnóstico por Imagem (Brazilian College of Radiology and Imaging Diagnosis) recommends annual mammographic screening for all women in the age range from 40 to 69 years, and mammography on an individual basis after such an age range ${ }^{(6)}$.

However, the mammographic screening started being followed by a high number of biopsies, and findings considered suspicious for malignancy may correspond to benign alterations. Thus, despite the high mammographic sensitivity and specificity, the positive predictive value (PPV) of biopsies reveals malignancy in only $15-40 \%$ of the procedures $^{(7,8)}$.

In order to ensure the early detection of breast cancer by mammography it is necessary that every diagnostic center has its activities carefully and systematically reviewed with the objective of verifying whether its results are in agreement with those reported in the literature ${ }^{(9-14)}$.

Therefore, the medical audit is essential to evaluate a mammography center performance and, for such a purpose it is necessary to analyze PPVs for each category, rate of breast cancer detection, rate of recommendation for biopsy, rate of recall, amongst other parameters, to evaluate the effectiveness of each diagnostic center project ${ }^{(15)}$.

The present study was aimed at undertaking a complete audit of a private institution mammography center, as recommended by BI-RADS ${ }^{\circledR}$, as well as comparing the results from such an audit with those reported in the literature.

\section{MATERIALS AND METHODS}

The present retrospective, analytical and cross-sectional study, involving a team with at least ten years of experience in breast imaging, undertook an internal audit of the results of the mammography center at FEMME - Laboratório da Mulher, São Paulo, SP, Brazil.

The study sample included patients enrolled in a single health plan of which the authors' institution was the only reference in diagnostic breast imaging. All the patients were referred by their respective doctors.

In the period from April 2010 to March 2011, 8,000 mammography studies were performed in the mentioned center, under the coverage of a single health plan, 7,249 of such studies in asymptomatic women with mean age of 66 years (age range $=33$ to 86 years) who were selected and submitted to audit based on their mammograms results.

The center has a Lorad Selenia full field digital mammography system, and the mammographic study includes the following steps: 1) completion of a standard form (includ- ing identification, origin, etc.); 2) anamnesis based on the center's records; 3) clinical assessment of the breasts, whose results are also recorded on the form; 4) mammographic images acquisition according to the protocol, under the guidance of the assisting physician.

The mammographic report includes the following topics:

Part 1 - Clinical data: patient's age, indication for the study, and clinical examination of the breasts.

Part 2 - Mammographic report itself, with description of the breasts pattern and radiological findings.

Part 3 - Radiological impression and classification corresponding to diagnostic impression and respective classification according to the Consensus about Mammographic Reports Standardization ${ }^{(16)}$ and BI-RADS ${ }^{(17,18)}$.

Part 4 - Notes: further data, recommendations for mammography repetition for each case, as a function of the mammographic findings.

The follow-up of the diagnostic outcomes extend from September 2010 to December 2012, as the patients returned to the center to undergo new mammographic studies.

The following exclusion criteria were taken into consideration for the purposes of the present study: 1) mammograms of symptomatic patients (with signs and symptoms of breast disease);2) mammographic studies covered by other health plans, since the follow-up of such cases was unfeasible.

\section{RESULTS}

Amongst the 8,000 mammographic studies selected in this study, $7,249(90.6 \%)$ were performed in asymptomatic women, and 751 in symptomatic women (diagnostic mammography), the latter excluded from the study.

The radiological classification of the 7,249 screening mammography studies according to BI-RADS is shown on Table 1.

Amongst the 7,249 asymptomatic patients, 826 presented mammographic alterations and classified as BI-RADS categories $0,3,4$ or 5 . In this group, 558 (67.5\%) patients were followed-up and 268 (32.5\%) were missed in the follow-up.

The relationship observed between the patients' age range and the diagnosed cases of cancer can be seen on Table 2 where one can also observe that most of the patients $(45.45 \%)$ were

Table 1-Distribution of mammographic cases according to BI-RADS categories.

\begin{tabular}{ccc}
\hline BI-RADS category & Number of cases & $\%$ \\
\hline 0 & 104 & 1.43 \\
1 & 567 & 7.82 \\
2 & 5,854 & 80.76 \\
3 & 605 & 8.35 \\
4 & 106 & 1.46 \\
5 & 11 & 0.15 \\
6 & 2 & 0.03 \\
Total & 7,249 & 100 \\
\hline
\end{tabular}


Table 2-Number of cancer cases detected per age range.

\begin{tabular}{cccc}
\hline $\begin{array}{c}\text { Age range } \\
\text { (years) }\end{array}$ & $\begin{array}{c}\text { Number } \\
\text { of patients }\end{array}$ & $\begin{array}{c}\text { Number of cancer } \\
\text { cases }\end{array}$ & $\%$ \\
\hline 30 to 39 & 21 & 0 & 0 \\
40 to 49 & 45 & 1 & 3.8 \\
50 to 59 & 1,424 & 5 & 15.4 \\
60 to 69 & 3,295 & 9 & 23.1 \\
70 to 79 & 2,464 & 20 & 57.7 \\
Total & 7,249 & 35 & 100 \\
\hline
\end{tabular}

included in the age range between 60 and 69 years, followed by $34 \%$ between 70 and 79 years, and $19.64 \%$ between 50 and 59 years.

Amongst the 165 biopsies performed for mammograms classified as BI-RADS categories 0, 3, 4 and 5, 35 patients presented malignant results at histopathological analysis, as follows: 1 case in category $0 ; 1$ in category $3 ; 26$ in category 4 ; and 7 in category 5. The PPVs of the percutaneous biopsies were calculated for each BI-RADS category of positive screening mammography, and the respective results are shown on Table 3.

Amongst the 35 cases which were positive for malignancy, $8(22.8 \%)$ were ductal carcinomas in situ (DCIS), $24(68.5 \%)$ invasive ductal carcinomas, and $3(9 \%)$ invasive lobular carcinomas.

In the present study, the authors observed 221 positive screening mammograms (BI-RADS categories 0, 4 and 5, with 104, 106 and 11 cases, respectively), and 7,026 negative screening mammograms (BI-RADS categories 1, 2 and 3 , with $567,5,854$ and 605 cases, respectively). Thirty-four cases of cancer were diagnosed by positive screening mammograms, while only one case was diagnosed to the present moment by negative screening mammography.

Table 3-Distribution of cases with percutaneous biopsy in agreement with $\mathrm{BI}$ RADS classification and histopathological diagnosis of malignancy or benignity.

\begin{tabular}{|c|c|c|c|c|c|c|}
\hline \multirow[b]{3}{*}{ BI-RADS } & \multicolumn{4}{|c|}{ Histopathological diagnosis } & & \\
\hline & \multicolumn{2}{|c|}{ Benign } & \multicolumn{2}{|c|}{ Malignant } & \multicolumn{2}{|c|}{ Total } \\
\hline & $n$ & $\%$ & $n$ & $\%$ & $n$ & $\%$ \\
\hline 0 & 17 & 94.5 & 1 & 5.5 & 18 & 10.90 \\
\hline 3 & 76 & 98.7 & 1 & 1.3 & 77 & 46.66 \\
\hline 4 & 37 & 58.7 & 26 & 41.3 & 63 & 38.18 \\
\hline 5 & 0 & 0 & 7 & 100 & 7 & 4.24 \\
\hline Total & 130 & & 35 & & 165 & 100 \\
\hline
\end{tabular}

BI-RADS 0: PPV 5.5\%; BI-RADS 3: PPV 1.3\%; BI-RADS 4: PPV 41.3\%; BIRADS 5: PPV 100\%.
Therefore, the present study recorded 34 true positive (TP) results, 187 false positive (FP) results, 7,025 true negative (TN) results, and 1 false negative (FN) result (Table 4$)$.

With such indicators, the authors could establish the calculations for sensitivity and specificity by means of the following equations: sensitivity $=\mathrm{TP}(\mathrm{TP}+\mathrm{FN})$ and specificity $=$ TN $(\mathrm{TN}+\mathrm{FP})$. Thus, sensitivity was $97.1 \%$, and specificity, $97.4 \%$.

In the present study, the rate of recall related to the number of cases requiring further investigation (BI-RADS category 0) was $1.43 \%$.

All the results observed in the present study and considered of interest for the purposes of the audit, are shown on Table $5^{(18-20)}$.

Table 5-Results clinically significant for the complete audit of the mammography center.

\begin{tabular}{lc}
\hline Item & Results \\
\hline 1. Total number of screening mammograms & 7,249 \\
2. Rate of recall & $104(1.43 \%)$ \\
3. Total number of cases classified as BI-RADS 4 & $106(1.46 \%)$ \\
4. Total number of cases classified as BI-RADS 5 & $11(0.15 \%)$ \\
5. Total number of cases classified as BI-RADS 4 and 5 & \\
submitted to percutaneous biopsy & 70 \\
5a. Number of such cases found to be benign & $36(51.4 \%)$ \\
5b. Number of such cases found to be malignant (PPV) & $34(48.6 \%)$ \\
6. Total number of cases of tumors in situ & $8(22.8 \%)$ \\
7. Total number of cases of invasive ductal/invasive lobular & \\
tumors & $27(77.2 \%)$ \\
8. Number of cases of cancer per 1,000 mammograms & 4.8 \\
9. Sensitivity & $97.1 \%$ \\
10. Specificity & $97.4 \%$ \\
\hline
\end{tabular}

\section{DISCUSSION}

The Brazilian radiological literature has recently been concerned with the role played by imaging methods in the improvement of breast diseases diagnosis ${ }^{(21-31)}$.

The detection of breast cancer at its earliest phases is the most effective measure in the management of the disease $^{(32,33)}$. The mammography's contribution to such an early detection is dependent on appropriate mammographic equipment utilized in the context of a quality program and under the supervision of a responsible physician ${ }^{(34)}$. Additionally, it is imprescindible that the clinical team is trained and experienced in breast imaging, and that the mammography studies are performed and supervised according to the best imaging techniques ${ }^{(35)}$.

Table 4-Mammography performance indicators (sensitivity and specificity).

\begin{tabular}{|c|c|c|c|}
\hline & & \multicolumn{2}{|c|}{ Biopsy results } \\
\hline & & $\begin{array}{c}\text { Positive (malignancy demonstrated } \\
\text { by biopsy within one year) }\end{array}$ & $\begin{array}{l}\text { Negative (benignity in biopsy study or } \\
\text { no cancer detected withir one year) }\end{array}$ \\
\hline \multirow{2}{*}{ Screening mammography } & Positive mammography (categories $0,4,5$ ) & $34(\mathrm{TP})$ & $187(\mathrm{FP})$ \\
\hline & Negative mammography (categories $1,2,3$ ) & $1(\mathrm{FN})$ & $7,025(\mathrm{TN})$ \\
\hline
\end{tabular}


The women's age range may affect the disease prevalence ${ }^{(13)}$. In the present study, mammography was performed in women in the age range between 33 and 86 years, and cancer was found in 35 of them. Breast cancer was detected in 4.8 per 1,000 patients, within the expected average range according BI-RADS, i.e., 2 to 10 cases per 1,000 mammo$\operatorname{grams}^{(19,20,32)}$.

The rate of recall represented by the number of women called or with indication for further investigation ${ }^{(36)}$ corresponded to $104(1.43 \%)$ patients, a number that is much inferior to the recommended standards $(5 \% \text { to } 10 \%)^{(14)}$. Such a fact is due to the acquisition of supplementary mammographic images at the moment of the routine mammography, as the physician evaluates the images before releasing the patient.

In the present study, the PPV based on percutaneous biopsy (TP results/number of biopsies in categories 4 and 5 ) was $48.6 \%$, superior to the expected range according to the literature $(15 \% \text { to } 40 \%)^{(14,37-42)}$. Remarkably, category 3 presented a PPV of $1.3 \%$, reproducing the values reported by Sickles et al. ${ }^{(37)}$. Table 6 compares the study results with those expected by relevant studies in the literature and correlates the data with the distribution of cases according to the BI-RADS classification.

Table 6-Distribution of cases according BI-RADS classification and predictive value for malignancy as compared with data in the literature ${ }^{\mathbf{1 4 , 3 7 - 4 2 )}}$.

\begin{tabular}{cccc}
\hline BI-RADS & $\begin{array}{c}\text { Distribution of cases according } \\
\text { to BI-RADS classification }\end{array}$ & $\begin{array}{c}\text { Observed } \\
\text { PPV }\end{array}$ & $\begin{array}{c}\text { Expected } \\
\text { PPV }\end{array}$ \\
\hline 0 & $104(1.43 \%)$ & $5.5 \%$ & $<10 \%$ \\
1 & $567(7.82 \%)$ & 0 & 0 \\
2 & $5,854(80.76 \%)$ & 0 & 0 \\
3 & $605(8.35 \%)$ & $1.3 \%$ & $<2 \%$ \\
4 & $106(1.46 \%)$ & $41.3 \%$ & $<30 \%$ \\
5 & $11(0.15 \%)$ & $100 \%$ & $95 \%$ \\
6 & $2(0.03 \%)$ & - & $100 \%$ \\
Total & $7,249(100 \%)$ & & \\
\hline
\end{tabular}

In the present study, the sensitivity was $97.1 \%$ because until the end of the patients follow-up, in December 2012, only one case of cancer (BI-RADS category 3 ) was found. Such a result is superior to the one reported by Sickles et al. $^{(37)}(93.1 \%)$ and by Baines et al. ${ }^{(38)}(69 \%)$, but reproduces the recommendations by Basset et al. ${ }^{(14)}(>85 \%)$. The specificity observed in the present study was $97.4 \%$ and studies in the literature recommend results $>90 \%(14,37,38,42)$. The authors attribute such results to the experience of the medical team (minimum 10-year training in breast imaging) and also to the quality of the mammography services provided by the center.

\section{CONCLUSION}

The complete internal audit of the mammography center is essential and depicts the quality of the service. The authors believe that the present study results reproduce the best results reported by international publications, ensuring the correct classification according BI-RADS categories, as well as the performance of appropriate percutaneous biopsies, thus contributing for the early breast cancer detection and reduction of the mortality associated with the disease.

\section{REFERENCES}

1. National Cancer Institute. Surveillance, Epidemiology and End Results (SEER). [acessado em 13 de agosto de 2012]. Disponível em: http://seer.cancer.gov.

2. Brasil. Ministério da Saúde. Instituto Nacional de Câncer. Estimativa 2012: incidência de câncer no Brasil. [acessado em 16 de agosto de 2012]. Disponível em: http://www.inca.gov.br/estimativa/2012.

3. Tabár L, Vitak B, Chen TH, et al. Swedish two-county trial: impact of mammographic screening on breast cancer mortality during 3 decades. Radiology. 2011;260:658-63.

4. Kopans DB, Smith RA, Duffy SW. Mammographic screening and "overdiagnosis". Radiology. 2011;260:616-20.

5. Miranda CMNR, Santos CJJ, Maranhão CPM, et al. A tomografia computadorizada multislice é ferramenta importante para o estadiamento e seguimento do câncer de mama? Radiol Bras. 2012;45: 105-12.

6. Urban LABD, Schaefer MB, Duarte DL, et al. Recomendações do Colégio Brasileiro de Radiologia e Diagnóstico por Imagem, da Sociedade Brasileira de Mastologia e da Federação Brasileira das Associações de Ginecologia e Obstetrícia para rastreamento do câncer de mama por métodos de imagem. Radiol Bras. 2012;45:334-9.

7. Kestelman FP, Souza GA, Thuler LC, et al. Breast Imaging Reporting and Data System - BI-RADS ${ }^{\circledR}$ : valor preditivo positivo das categorias 3, 4 e 5 . Revisão sistemática da literatura. Radiol Bras. 2007;40:173-7.

8. Hall FM, Storella JM, Siverstone DZ, et al. Nonpalpable breast lesions: recommendations for biopsy based on suspicion of carcinoma at mammography. Radiology. 1988;167:353-8.

9. Clark R, Geller B, Peluso N, et al. Development of a community mammography registry: experience in the breast screening program project. Radiology. 1995;196:811-5.

10. Daly CA, Apthorp L, Field S. Second round cancers: how many were visible on the first round of the UK National Breast Screening Programme, three years earlier? Clin Radiol. 1998;53:25-8.

11. May DS, Lee NC, Nadel MR, et al. The National Breast and Cervical Cancer Early Detection Program: report on the first 4 years of mammography provided to medically underserved women. AJR Am J Roentgenol. 1998;170:97-104.

12. Spring DB, Kimbrell-Wilmot K. Evaluating the success of mammography at the local level: how to conduct an audit of your practice. Radiol Clin North Am. 1987;25:983-92.

13. Tabár L, Fagerberg CJ, Gad A, et al. Reduction in mortality from breast cancer after mass screening with mammography. Randomised trial from the Breast Cancer Screening Working Group of the Swedish National Board of Health and Welfare. Lancet. 1985;1: 829-32.

14. Bassett LW, Hendrick RE, Bassford TL, et al. Quality determinants of mammography. Clinical practice guideline No. 13. AHCPR Publication No. 95-0632. Rockville, MD: Agency for Health Care Policy and Research, Public Health Service, U.S. Department of Health and Human Services. October 1994.

15. Robertson CL. A private breast imaging practice medical audit of 25,788 screening and 1,077 diagnostic examinations. Radiology. 1993;187:75-9.

16. Santor RP, Koch HA, Menke CH, et al. I Reunião de consenso para padronização dos laudos mamográficos. Femina. 1998;26:625-6.

17. Kopans DB, D’Orsi CJ, Adler DD, et al. Breast Imaging Reporting and Data System (BI-RADS). Reston, VA: American College of Radiology; 1998. 
18. Colégio Brasileiro de Radiologia. BI-RADS - Sistema de laudos e registro de dados de imagem da mama. São Paulo, SP: Colégio Brasileiro de Radiologia; 2005.

19. American College of Radiology. Breast Imaging Reporting and Data System (BI-RADS). Reston, VA: American College of Radiology; 1993.

20. American College of Radiology. Breast Imaging Reporting and Data System (BI-RADS®). 4th ed. Reston, VA: American College of Radiology; 2003.

21. Rodrigues DCN, Freitas-Junior R, Corrêa RS, et al. Avaliação do desempenho dos centros de diagnóstico na classificação dos laudos mamográficos em rastreamento oportunista do Sistema Único de Saúde (SUS). Radiol Bras. 2013;46:149-55.

22. Vianna AD, Gasparetto TD, Torres GC, et al. Cancerização de lóbulos: correlação de achados mamográficos e histológicos. Radiol Bras. $2011 ; 44: 275-8$.

23. Marques EF, Medeiros MLL, Souza JA, et al. Indicações de ressonância magnética das mamas em um centro de referência em oncologia. Radiol Bras. 2011;44:363-6.

24. Calas MJG, Gutfilen B, Pereira WCA. CAD e mamografia: por que usar esta ferramenta? Radiol Bras. 2012;45:46-52.

25. Oliveira FGFT, Fonseca LMB, Koch HA. Responsabilidade civil do radiologista no diagnóstico do câncer de mama através do exame de mamografia. Radiol Bras. 2011;44:183-7.

26. Moreira BL, Lima ENP, Bitencourt AGV, et al. Metástase na mama originada de carcinoma ovariano: relato de caso e revisão da literatura. Radiol Bras. 2012;45:123-5.

27. Alvares BR, Freitas CHA, Jales RM, et al. Densidade mamográfica em mulheres menopausadas assintomáticas: correlação com dados clínicos e exames ultrassonográficos. Radiol Bras. 2012;45:149-54.

28. Criado DAB, Braojos FDC, Torres US, et al. Preenchimento estético das mamas com ácido hialurônico: aspectos de imagem e implicações sobre a avaliação radiológica. Radiol Bras. 2012;45:181-3.

29. Barra FR, Barra RR, Barra Sobrinho A. Novos métodos funcionais na avaliação de lesões mamárias. Radiol Bras. 2012;45:340-4.

30. Calas MJG, Alvarenga AV, Gutfilen B, et al. Avaliação de parâmetros morfométricos calculados a partir do contorno de lesões de mama em ultrassonografias na distinção das categorias do sistema BI-RADS. Radiol Bras. 2011;44:289-96.
31. Lykawka R, Biasi P, Guerini CR, et al. Avaliação dos diferentes métodos de medida de força de compressão em três equipamentos mamográficos diferentes. Radiol Bras. 2011;44:172-6.

32. Koch HA, Peixoto JE. Bases para um programa de detecção precoce do câncer de mama por meio da mamografia. Radiol Bras. 1998;31: 329-37.

33. Sickles EA. Periodic mammographic follow-up of probably benign lesions: results in 3,184 consecutive cases. Radiology. 1991;179: 463-8.

34. Goto RE, Pires SR, Medeiros RB. Identificação de parâmetros de qualidade de impressão para a garantia da detecção de estruturas presentes na mamografia digital. Radiol Bras. 2013;46:156-62.

35. Wilson TE, Helvie MA, August DA. Breast cancer in the elderly patient: early detection with mammography. Radiology. 1994;190: 203-7.

36. Orel SG, Kay N, Reynolds C, et al. BI-RADS categorization as a predictor of malignancy. Radiology. 1999;21 1:845-50.

37. Sickles EA, Ominsky SH, Sollitto RA, et al. Medical audit of a rapidthroughput mammography screening practice: methodology and results of 27,114 examinations. Radiology. 1990;175:323-7.

38. Baines CJ, Miller AB, Wall C, et al. Sensitivity and specificity of first screen mammography in the Canadian National Breast Screening Study: a preliminary report from five centers. Radiology. 1986;160:295-8.

39. Roveda Jr D, Piato S, Oliveira VM, et al. Valores preditivos das categorias 3, 4 e 5 do sistema BI-RADS em lesões mamárias nodulares não palpáveis avaliadas por mamografia, ultra-sonografia e ressonância magnética. Radiol Bras. 2007;40:93-8.

40. Melhado CV, Alvares RB, Almeida JO. Correlação radiológica e histológica de lesões mamárias não palpáveis em pacientes submetidas a marcação pré-cirúrgica, utilizando-se o sistema BI-RADS. Radiol Bras. 2007;40:9-11.

41. Godinho ER, Koch HA. Breast Imaging Reporting and Data System (BI-RADS): como tem sido utilizado? Radiol Bras. 2004;37: 413-7.

42. Azevedo AC, Koch HA, Canella EO. Auditoria em centro de diagnóstico mamário para detecção precoce de câncer de mama. Radiol Bras. 2005;38:431-4. 